Author version: Mar. Geol., vol.275(1-4); 2010; 221-229

\title{
Late Quaternary record of pteropod preservation from the Andaman Sea
}

\author{
A.V.Sijinkumar ${ }^{\mathrm{a}, \mathrm{b}}, *$, B. Nagender Nath ${ }^{\mathrm{a}}$, M.V.S. Guptha ${ }^{\mathrm{a}, \mathrm{c}}$ \\ ${ }^{a}$ National Institute of Oceanography (Council of Scientific and Industrial Research), \\ Dona Paula, Goa, 403004, India
}

\begin{abstract}
In order to understand the glacial to interglacial fluctuations in pteropod preservation and productivity during the late Quaternary ( $\sim 54 \mathrm{ka} \mathrm{BP}$ to present), we investigated pteropod, organic carbon $\left(\mathrm{C}_{\text {org }}\right)$ and G. bulloides abundance in a deep sea core from the western Andaman Sea. Pteropod abundance and preservation is similar to the "Indo-Pacific carbonate preservation type", showing better preservation during glacial and poor preservation during interglacial periods. The core site appears to have remained below the aragonite compensation depth (ACD) throughout the Holocene, indicated by the total absence of pteropods. Maximum abundance and good preservation of pteropods was observed during stadials such as Younger Dryas (YD), Heinrich Events (HEs) and Last Glacial Maxima (LGM) indicating weaker oxygen minimum zone (OMZ) and deeper ACD. Furthermore, the high relative abundance of mesopelagic pteropods over epipelagic forms suggests a well ventilated water column with weak OMZ particularly during LGM, apparently driven by intense winter monsoon. Increased monsoon-driven productivity was observed during 45-40 ka, of early Marine Isotope Stage 2 (MIS 2, 24-22 ka), Bølling/Allerød (B/A; 15-13.5 ka), YD and Late Holocene as evidenced by $\mathrm{C}_{\text {org }}$ content and G. bulloides. Enhanced pteropod preservation of $\mathrm{H} 1$ associated with low $\mathrm{C}_{\text {org }}$ content and G. bulloides suggests that reduced monsoonal driven productivity might have influenced pteropod preservation. Deglacial preservation spike in the Andaman Sea is consistent with other northern Indian Ocean records and elsewhere outside the Indian Ocean implying the event is global in nature, marked by deepening of ACD probably driven by enhancement of winter monsoon on local and changes in intermediate water circulation on regional scale.
\end{abstract}

Keywords: Andaman Sea; pteropod preservation; aragonite compensation depth; late Quaternary; oxygen minimum zone; Paleoceanography.

$\mathrm{b}_{\text {, }}$ Corresponding author. Permanent Address: Department of Post Graduate Studies \& Research in Geology, Govt. College Kasaragod, Kerala, 671123, India

Tel. +91 9447731175; Fax: +91 8322450609, E-mail address: sijingeo@gmail.com

${ }^{\mathrm{c}}$ Present address: 62, Sagar Society, Dona Paula, Goa, 403004, India 


\section{Introduction}

Carbonate production, accumulation and dissolution in the pelagic environments play vital role in global carbon cycling. Besides, planktic foraminifera and coccoliths, pteropods represent an important constituent of oceanic plankton, which play dominant role in oceanic $\mathrm{CO}_{2}$ system (Berner and Honjo, 1981). Pteropods are marine gastropods known as "sea butterflies", common members of calcareous zooplankton communities in the upper ocean (Bè and Gilmer, 1977; Almogi-Labin et al., 1998). The preservation and accumulation of pteropods on the seafloor is related to the changes in water masses and their properties (e.g. Klöcker et al., 2006). Their shells are composed of aragonite, a metastable polymorph of $\mathrm{CaCO}_{3}$ which is more susceptible to dissolution than calcite in sea water (Mucci, 1983; Millero, 1996; Morse and Arvidsen, 2002). Therefore, the aragonite lysocline and aragonite compensation depth (ACD) are much shallower than the carbonate compensation depth (CCD). Of the total $\mathrm{CaCO}_{3}$ produced in oceans, pteropods contribute about $\sim 10-12 \%$ (Berner and Honjo, 1981; Fabry, 1990; Fabry and Deuser, 1991, 1992), occasionally reaching $>50 \%$ in some areas (Lalli and Gilmer, 1989). Bè and Gilmer (1977) were the first to report a detailed zoogeographic and taxonomic review of pteropods from the world oceans. Berger (1978) investigated pteropods in marine sediments and published a global map, showing the ACD and optimum depth limits of pteropod preservation and thus facilitating their use as bathymetric indicators (Herman and Rosenberg, 1969). Pteropods exhibit two important life strategies, i.e., epipelagic [non migratory species that live in the mixed layer $(0-100 \mathrm{~m})$ ] and mesopelagic [migratory species that inhabit the intermediate water mass and migrate diurnally]. The latter are, because of their migrations sensitive to changes in water column stratification and OMZ intensity.

Generally, high abundance of pteropods are restricted to shallow and subtropical seas such as Arabian Sea (Herman and Rosenberg, 1969; Singh, 1998), Red Sea and Mediterranean Sea (AlmogiLabin and Reiss, 1977; Reiss et al., 1980; Almogi-Labin, 1982; Almogi-Labin et al., 1986, 1991; Wang et al., 1997). The preservation of aragonite along the Pakistan continental margin was investigated by Berger (1977, 1978); Reichart et al. (1998, 2002); von Rad et al. (1999) and Klöcker and Heinrich (2006) and off Somalia Margin by Ivanova (2000) and Klöcker et al. (2006), Murray Ridge by Reichart et al. (1998), Gulf of Aden by Almogi-Labin et al. (2000) and the northern Arabian Sea by Böning and Bard (2009). All these studies carried out so far in the northern Indian Ocean are confined to the western 
part. Aragonite preservation in the eastern part of the northern Indian Ocean, Bay of Bengal (BOB) and the Andaman Sea, and changes therein through time, are virtually unknown.

The world's highest physical and chemical erosion rates are found in the Himalayan Rivers. The Himalayan Rivers contribute enormous quantities of sediments to the BOB and Andaman Sea, thus providing a record of climate variability. Sediments of the Andaman Sea are largely derived from Ayeyarwady, Salween and Sittang rivers (Rodolfo, 1969). Moderate to high sedimentation rates in this basin allow the construction of paleo records with a high temporal resolution. The present day ACD of Andaman Sea lies at about $1200 \mathrm{~m}$ depth (Bhattacharjee and Bandyopadhyay, 2002), ACD fluctuations with time however are not known. Because the depth of the ACD provides important constraints on Andaman Sea circulation, an attempt is made here to understand the late Quaternary (last $54 \mathrm{ka}$ ) record of pteropod preservation.

\section{Oceanographic setting}

The Andaman Sea (AS) is a marginal sea, in the eastern part of the north East Indian Ocean situated between the east of Andaman Nicobar Ridge (ANR) and west of Malayan Peninsula, with a maximum water depth of $4400 \mathrm{~m}$. It is interconnected with the BOB by the Deep Prepares Channel, Ten Degree Channel and the Great Channel. The oceanographic processes in these seas are however comparable only up to a depth of about $1000 \mathrm{~m}$, as the deep water exchange between these two region (AS and BOB) is hampered by several sills (Fig. 1a). Similar to the Arabian Sea, the Andaman Sea experiences a seasonal reversal in surface circulation, driven by the Indian monsoon. Biological productivity in offshore region is $\sim 0.8-1.0 \mathrm{mgC} / \mathrm{m}^{2} / \mathrm{d}$ which is higher than the $<0.6 \mathrm{mgC} / \mathrm{m}^{2} / \mathrm{d}$ observed in coastal areas of the Andaman Sea (Janekarn and Hylleberg, 1989). Surface water salinities range between 31.8 and 33.4\% (Sarma and Narvekar, 2001) (Fig. 1b), due to the large fresh water discharges from the Ayeyarwady-Salween river system (Janekarn and Hylleberg, 1989; Varkey et al., 1996). It is estimated that Ayeyarwady River drains $\sim 428 \mathrm{~km}^{3}$ of fresh-water annually from the Ayeyarwady catchment region to the Andaman Sea (Milliman and Meade, 1983). Most of the outflow occurs during the summer to late fall, with a peak during October. Surface water temperature of the Andaman Sea is $29^{\circ} \mathrm{C}$, with a mixed layer of up to $50 \mathrm{~m}$, resulting in intense stratification, which hinders vertical mixing (Sarma and Narvekar, 2001). Deep Andaman Sea water is consistently warmer than that of BOB with an approximate offset of $2^{\circ} \mathrm{C}$ (Sarma and Narvekar, 2001), which can be attributed to the enclosed nature of 
the Andaman Basin (Rao and Jayaraman, 1968, Sengupta, 1981) or the sinking of intermediate BOB waters into the Andaman deep (Naqvi et al., 1994). The high temperature of the deeper water lowers the ACD.

\section{Material and Methods}

A sediment core SK 168/GC-1 was collected (Lat $11^{\circ} 42.463^{\prime} \mathrm{N}$; Long 94²9.606' E, water depth: 2064 m, core length: $4.20 \mathrm{~m}$ ) during the $168^{\text {th }}$ cruise of ORV Sagar Kanya from the Alcock Seamount Complex in the Andaman Sea (Fig.1a). The core was sub sampled at a $2 \mathrm{~cm}$ interval down to $52 \mathrm{~cm}, 2-3$ $\mathrm{cm}$ interval down to $200 \mathrm{~cm}$ and at every $5 \mathrm{~cm}$ interval down to $420 \mathrm{~cm}$. The core comprises three distinct sediment layers, dark yellowish brown colored clays in the top $10 \mathrm{~cm}$ and olive gray sediments between $30 \mathrm{~cm}$ to $420 \mathrm{~cm}$ (bottom of the core), while the $20 \mathrm{~cm}$ section of light olive gray sediments is sandwiched between these two layers. These sediments are extremely sticky and dominantly clayey in texture, containing tests of foraminifera. The age model for the core is constructed mainly by using Accelerator Mass Spectrometer (AMS) ${ }^{14} \mathrm{C}$ dates of planktic foraminiferal tests (mixed Globigerinoides ruber and Globigerinoides sacculifer) (Table 1). AMS ${ }^{14} \mathrm{C}$ ages were determined at five different intervals at NOSAMS facility at WHOI, USA and ages were converted to calendar ages using the CalPal 2007 Programme (Weninger et al., 2007; http://www.calpal.de). The AMS ${ }^{14} \mathrm{C}$ ages were corrected for a 460 year reservoir age following Butzin et al. (2005). In addition, oxygen isotope stratigraphy was established by correlating the oxygen isotopic values of G. ruber (Fig. 2a) with the standard oxygen isotopic curve of Martinson et al. (1987). The fourth point of the age model is taken from the oxygen isotope boundary between MIS 2 and MIS 3. The ages for other horizons were assigned by interpolation/extrapolation of calibrated dates, assuming constant sedimentation rates. The average sedimentation rate worked out to $\sim 7.79 \mathrm{~cm} / \mathrm{ka}$. The sedimentation rate was high during the Pleistocene to Holocene transition and low during the MIS 3/MIS 2 transition (Fig. 2b). Comparing the isotopic record of core SK 168/GC 1 with the standard isotopic stratigraphy suggests that the core provides a continuous high resolution record for the last 54 cal $\mathrm{ka}$, displaying distinct glacial to interglacial transitions.

About $10 \mathrm{~g}$ of dried samples were soaked in milli-Q water overnight and washed through a $63 \mu \mathrm{m}$ mesh sieve. Later the dried filtrate was sieved over a $125 \mu \mathrm{m}$ mesh sieve. The samples were split into several aliquots to reduce the total number to a minimum of 300 individuals. The coarse fraction $(>125$ 
$\mu \mathrm{m})$ was used for quantitative and qualitative analysis of pteropod assemblages under a stereo zoom binocular microscope. The same fraction was used for counting dissolution resistant species of planktic foraminifera (Total percentage of P. obliquiloculata, G. menardii, N. dutertrei and S. dehiscence) and G. bulloides. The pteropod species were identified following Van der Spoel (1967), Bè and Gilmer (1977) and Almogi-Labin (1982). All pteropod shells were identified, counted and computed as absolute number per gram of dry sediment. Pteropod fragments were also counted and the fragmentation ratio was computed using the expression $n_{F} /\left(n_{F}+n_{W}\right)$, where $n_{F}$ is the number of fragments and $n_{W}$ is the number of whole tests (Klöcker et al., 2006). Carbonate carbon was determined by Coulometer, after acid reaction to release $\mathrm{CO}_{2}$, whereas the total carbon was measured by CNS analyzer. The organic carbon was estimated from the difference between total carbon and carbonate carbon.

\section{Results}

In total 13 species of pteropods were identified (Table 2) which indicates a low diversity. The species comprise both mesopelagic and epipelagic forms with a high dominance of mesopelagic forms, ranging from $60-80 \%$ of total pteropods. Fossil pteropod diversity in the Andaman Sea is lower than that in the surface sediments of NW Indian Ocean (Sakthivel, 1968), but comparable to the assemblages of the eastern Arabian Sea (Singh et al., 2006). Maximum diversity of species was noticed in MIS 2, especially during the time equivalents of YD, H1 and LGM. On the contrary, MIS 3 is characterized by a low diversity, whereas during the Holocene pteropods are completely absent (Fig. 3a-g). The Andaman Sea ACD lies at about 1200 m (Bhattacharjee and Bandyopadhyay, 2002), whereas aragonite saturation depth (ASD) is situated at $\sim 300 \mathrm{~m}$ (Sarma and Narvekar, 2001). The core location/site was below the ASD and ACD, which is believed to have remained stable throughout the Holocene. Limacina inflata, a mesopelagic warm belt species which does not live in high latitudes (Bè and Gilmer, 1977) was most dominant among the pteropod assemblage being almost monospecifc at certain depths. The down core variation in $L$. inflata is similar to the total pteropod abundance variation (Fig. 3a), with maximum abundances observed during YD and HE 1 (Fig. 3b). Similarly, all other major species showed maximum abundance during these episodes with better preservation (Fig. 3c-g).

The oxygen isotope stratigraphy of G. ruber along with sedimentation rate of core SK 168/GC 1 is shown in Fig. 2a,b. Carbonate/aragonite dissolution proxies are depicted in Fig. 4a-c. Percentage of dissolution resistant planktic foraminiferal species is higher during late MIS 3 and lower during YD, H1 
and LGM (Fig. 4c). The $\mathrm{C}_{\text {org }}$ values range between 0.8 and $1.7 \%$, with higher values occurring during ca. 45-40 ka, early MIS 2 (ca. 24-22.5 ka), B/A (ca. 15-13.5 ka) and late Holocene (ca. 6-1 ka BP) whereas low $\mathrm{C}_{\text {org }}$ values occur during early MIS 3 (ca. 54-51.5 ka), late glacial (ca. 19-16.5 Ka), YD (ca. 13-11.5 ka) and HE (H1=ca. 17.5-16, H2=25-23.5, H3=32-30, H4=38-37 ka) (Fig. 4d). The low $\mathrm{C}_{\text {org }}$ values and G. bulloides\% during H1/late LGM coincide with pteropod maximum abundance (ca. 19-16 ka BP). The G. bulloides is an important upwelling indicator species which occur throughout the core and range between 1.5 and $20 \%$ of total planktic foraminifera. Its maximum abundance is seen during the last glacial-interglacial transition and the minimum abundance is seen at LGM (Fig. 4e). Late Quaternary pteropod preservation of Andaman Sea and Arabian Sea records are compared in Fig. 5a-g.

\section{Discussion}

\subsection{Pteropod abundance and preservation in relation to monsoon induced productivity, OMZ and ACD} fluctuations.

Pteropod abundance and good preservation during $\mathrm{H} 1$ is coinciding with low $\mathrm{C}_{\text {org }}$ content and $G$. bulloides\%, whereas moderate to good preservation during YD is paralleled with enhanced upwelling and productivity (Fig. 5). During periods of weaker summer monsoon viz., late glacial and HE, the abundance of well preserved pteropods sharply increased, whereas during MIS 1 and B/A when summer monsoon was stronger, pteropod preservation is poor leading to decrease in their abundance. Earlier studies from Andaman Sea showed that summer monsoon was stronger during B/A and Holocene and weaker during late glacial (Rashid et al., 2007). Several studies from the Arabian Sea also showed that the interglacial and inter stadials are characterized by enhanced upwelling and productivity induced by strong summer monsoon (Sirocko et al., 1993; Reichart et al., 1998; Schulz et al., 1998; Schulte and Muller, 2001). The study from BOB and Andaman Sea revealed that the rapid cold events of north Atlantic during the last glacial stages and HE are characterized by a weaker summer monsoon over the

Himalaya via an atmospheric teleconnection (Colin et al., 1998). Duplessy (1982) and Sarkar et al. (1990) reported that during the LGM, the summer monsoon was weaker than present, while winter monsoon was stronger. Therefore, the high abundance of pteropod, low abundance of G. bulloides and moderate $\mathrm{C}_{\text {org }}$ content during LGM to $\mathrm{H} 1$ indicates enhanced pteropod preservation during periods characterized by strong winter monsoon. Whereas enhanced monsoon related productivity during YD has not affected pteropod preservation which may be related to the ventilation changes during this time. 
Upwelling and resulting high biological productivity greatly affects the preservation of sedimentary carbonates, particularly pteropods owing to their vulnerability to dissolution. Globally upwelling regions are characterized by poor pteropod preservation (Berger, 1978; Ganssen and Lutze, 1982; Gerhardt and Heinrich, 2001), which is attributed to high concentration of dissolved inorganic carbon (DIC), resulting from high input and remineralisation of organic matter, lowering the $\mathrm{pH}$ (Millero et al., 1998). Supralysoclinal or biologically mediated carbonate dissolution through decomposition of organic matter within the sediments lowers pore water pH (Milliman et al., 1999). The Andaman Sea is less affected by summer monsoon induced productivity and the relatively low $\mathrm{C}_{\mathrm{org}}$ values throughout the core may be attributed to the limited upwelling in the western Andaman Sea, compared to Arabian Sea. During summer, strong stratification caused by increased fresh water influx and weakened winds inhibit upwelling of nutrient rich water. During glacial time, weaker summer monsoon and increased winter monsoon resulting in vertical mixing, good ventilation would increase the ACD favoring pteropod preservation. Rostek et al. (1997) suggested that a lower SST and increased $\mathrm{C}_{\text {org }}$ accumulation rates during glacial stages may be related to an intensified winter monsoon. Since productivity in the Andaman Sea is directly related to the strength of the winter monsoon winds by overturning of the mixed layer due to excess cooling, pteropod preservation in Andaman Sea potentially reflects winter monsoon variability.

Pteropod abundance has been used as a proxy for OMZ intensity and ACD fluctuation in the Red Sea and northern Arabian Sea (Almogi-Labin et al., 1986, 1998; Reichart et al., 1998). Variations in the relative abundance of epipelagic and mesopelagic pteropods were used to construct fluctuations in the nature of OMZ in central Red Sea (Almogi-Labin, 1986, 1991), which is related to climatic fluctuations. Similarly, Rai et al. (2008) used pteropod abundance changes for reconstructing the intensity of the $\mathrm{OMZ}$ in the north western Arabian Sea. Aragonite variability in the $50 \mathrm{ka}$ record from the NE Arabian Sea was also found to be driven by OMZ intensity variations (Böning and Bard, 2009). High abundance of mesopelagic taxon in Andaman Sea suggests the existence of significant ventilation of deep water during glacial time due to enhanced deep winter mixing resulted by weaker OMZ and deepening of ACD. 


\subsection{Late Quaternary pteropod preservation in the Andaman Sea}

The dissolution proxies such as fragmentation ratio and relative abundance of dissolution resistant foraminiferal species, all point towards better preservation during the last glacial stage (Fig. 4a-c). Several proxies are used to understand pattern of changes in carbonate preservation indicated by foraminiferal proxies (Ruddiman and Heezen, 1967; Berger, 1975; Diester-Haass, 1977; Peterson and Prell, 1985; Volbers and Heinrich, 2002). Although Limacina Dissolution Index (LDX) is considered an efficient tool to understand subtle changes in aragonite preservation (Gerhardt and Heinrich, 2001; Klöcker et al., 2006), this proxy could not be applied here because of the rare occurrence of different types (transparent and opaque) of L. inflata. However, some transparent $L$. inflata species were observed during YD, H1 and late glacial, suggesting a good preservation at those times. The state of preservation of pteropods, displaying distinct variation throughout the core length and the preservation records of the Andaman Sea are in good agreement with other records from the northern Indian Ocean (Fig. 5) where a good preservation was observed during YD and HE. The pteropod abundance corresponds well with the 'Indo Pacific carbonate preservation type' with good preservation during glacials (Almogi-Labin et al., 2000).

We have further explored past salinity variations in order to understand its effect on change in pteropod abundance. The pteropods are very sensitive to salinity changes and stenohaline in nature and are known to occur mainly in the salinity range of 31 to 34\%o (Rottman, 1978, 1980). Present day surface water salinity of Andaman Sea ranges between 31.8 and 33.4\%o (Sarma and Narvekar, 2001) which is within the range of suitable salinity limits. The oxygen isotope record of G. ruber in this core has shown that the LGM to Holocene $\left(\Delta \delta{ }^{18} \mathrm{O}\right)$ amplitude is $2.09 \%$ from which the global ice volume effect would account for $1.2 \%$ and remaining $0.90 \%$ would either require an increase in salinity by $3 \%$ or a decrease in temperature by $\sim 4.5^{\circ} \mathrm{C}$. In Andaman Sea, the $\mathrm{Mg} / \mathrm{Ca}$ records have shown that the LGM temperature is $3^{\circ} \mathrm{C}$ less than that seen presently or during Holocene (Rashid et al., 2007). This temperature change would thus account for an enrichment of $0.60 \%$ and the remaining $0.30 \%$ (of LGM to Holocene $\Delta \delta{ }^{18} \mathrm{O}$ amplitude) will require an increase in salinity by $1 \%$ during LGM. This agrees with

the estimate of 1\% higher salinity during LGM in north eastern Indian Ocean (Cullen, 1981). Considering a suitable salinity range of $31-34 \%$ for pteropod abundance, a change in salinity by $1 \%$ o would not influence their numerical abundance and suggests that salinity changes may have played a minor role in pteropod variability in the area studied. 
Pteropod abundance/preservation is poor during Holocene in the Indian Ocean, and pteropods are completely absent at most water depths from 7-10 ka in all the records except the Red Sea where Holocene is characterized by good pteropod preservation (Almogi-Labin et al., 1998). According to Klöcker et al. (2006) and Klöcker and Heinrich (2006) the absence of pteropods (core 905, water depth: $1586 \mathrm{~m}$ and core 137KA, water depth: $573 \mathrm{~m}$ ) in the Somali Basin and northern Arabian Sea are due to strong dissolution. The total absence of pteropods during Holocene may be attributed to several reasons. First, the core site may have remained below the ACD throughout the Holocene. Second, upwelling and resulting high biological productivity, caused by strong summer monsoon, affected pteropod preservation by enhancing local $\mathrm{CO}_{2}$ production. Last, increased concentration in atmospheric $\mathrm{CO}_{2}$ during Holocene resulting in acidic water, reducing the saturation state of the oceans with respect to calcium carbonate (Kleypas et al., 1999; Feely et al., 2004)

\subsection{Regional/global deglacial preservation pattern}

Pteropod preservation data of the present study from the Andaman Sea is compared with the late Quaternary record of pteropod preservation from other parts of the northern Indian Ocean viz., the eastern and western Arabian Sea and Gulf of Aden (Table 3 and Fig. 5) and shows a synchronous preservation pattern suggesting a regional nature of pteropod preservation during last deglacial. The timing of this preservation spike of Indian Ocean is consistent within a broad age frame of 19-13 ka. The exact timing of Andaman Sea preservation spike is 19-16 ka for core SK 168/GC 1 and 18.5-16.2 ka for deeper core AAS 11/GC 1 (Fig. 5a,b). In Eastern Arabian Sea, the preservation spike off Goa is seen at 17.8-15 ka (Singh et al., 2006; Fig. 5c) and off Pakistan coast between 17 and 15 ka (Klöcker and Heinrich, 2006; Fig. 5d). In Gulf of Aden, the preservation spike is seen between 18.8 and 14 ka (Almogi-Labin et al., 2000; Fig. 5e) and off Somalia in the western Arabian Sea, preservation spike is seen between 17 and 13 ka (Klöcker et al., 2006; Fig. 5f). A recent record of high aragonite content (determined using X-ray diffractometry) is also reported from the northern Arabian Sea between 18 and 14.4 ka (Böning and Bard, 2009; Fig. 5g). Outside northern Indian Ocean, the preservation spike is seen in records from coast of Morocco (Diester-Haass et al., 1973), Pacific Ocean (Berger, 1977) and South China Sea (Wang et al., 1997) all implying the event could be global in nature (Berger, 1977). Deglacial preservation events provide good constraints on the carbonate ion concentration of the deep ocean resultant with ventilation changes during glacial interglacial climate change. While the better preservation has been variously attributed, either to red tide induced mass mortality (Diester-Haas and 
Van der Spoel, 1978), or to the rapid growth of biosphere during deglaciation leading to the extraction of atmospheric $\mathrm{CO}_{2}$ and carbonate preservation (Shackleton, 1977), or a combination of increased saturation of deep waters, decreasing bottom currents and increased sedimentation rates (Berger, 1977). However, according to a recent report, the good aragonite preservation in Arabian Sea is attributed to enhanced ventilation and strengthened influx of Subantarctic Mode and Antarctic Intermediate Waters (SAMW-AAIW) and weakening of OMZ (Böning and Bard, 2009). Lower pteropod preservation during the Holocene and DO interstadials was attributed by them to low supply of $\mathrm{O}_{2}$ combined with elevated $\mathrm{O}_{2}$ demand controlled by monsoon-related productivity.

In the Andaman Sea, the AAIW enters through the shallow sills connected with Bay of Bengal as a mixture of overlying water mass containing SAMW, AAIW and the high salinity outflows from the Persian Gulf and the Red Sea and the underlying NADW (Naqvi et al., 1994). If the preservation pattern is global (or a regional feature comprising the entire Northern Indian Ocean), this must be due to a largescale climatic feature. Best preservation is seen during early to mid-deglaciation in the Andaman Sea followed by a good preservation event during YD. High resolution records of carbon and oxygen isotope records of benthic foraminifera from the Andaman Sea has shown rapid increases in $\delta^{13} \mathrm{C}$ occurring in two stages during the early deglaciation in response to fluctuations in the NADW production (Naqvi et.al., 1994). The YD pteropod preservation event is the only one which coincides with intensified summer monsoon (G. bulloides), when the benthic $\delta^{13} \mathrm{C}$ record has shown a pronounced negative excursion to near-glacial values and has been considered more as a regional event (Naqvi et.al., 1994) due to the enhanced nutrient regeneration in the intermediate waters due to the intensified monsoon.

\section{Conclusion}

The absolute abundance records of pteropods, $\mathrm{C}_{\mathrm{org}}$ and percent of $G$. bulloides from the Andaman Sea spanning the last 54 ka showed a large variability during the last glacial and into the Holocene. The pteropod abundance and preservation pattern is analogous to the "Indo-Pacific carbonate preservation type", with better preservation during glacial periods and poor preservation during the interglacial. The total absence of pteropods during Holocene may be related to the core location which may have remained well below the present day ACD throughout the Holocene. Maximum abundance/good preservation of pteropods was observed during stadials like YD, HE 1 and LGM, due to a weaker OMZ and thus deeper ACD. Furthermore, the high relative abundance of mesopelagic pteropods over 
epipelagic forms indicates a deep mixed layer with weak OMZ especially during the LGM to deglacial, probably driven by an intense winter monsoon by vertical mixing and good ventilation. The carbonate dissolution indices along with presence of transparent $L$. inflata suggest good preservation, whereas the low abundance of dissolution resistant planktic foraminifera confirm weak dissolution during YD, HE 1 and late glacial. Increased monsoon-driven productivity was seen during 45-40 ka, early MIS 2 (24-22 ka), B/A (15-13.5 ka), YD and Late Holocene. Low $\mathrm{C}_{\text {org }}$ content and G. bulloides during pteropods spike (19-16 ka) suggesting a regional monsoonal influence on deep water chemistry controlling pteropod preservation. Deglacial preservation spike in the Andaman Sea is consistent with other northern Indian Ocean records and elsewhere outside the Indian Ocean implying the event is global in nature which is marked by deepening of ACD probably driven by enhancement of winter monsoon and changes in intermediate water circulation.

\section{Acknowledgement}

We thank the Director of the National Institute of Oceanography, Goa, for permission to publish this research. Dr. K.A. Kamesh Raju Project Leader Ridge Studies, is sincerely thanked for his constant encouragement and support. Ministry of Earth Science (formerly Department of Ocean Development, Govt. of India) New Delhi is thanked for providing ship time. Captain and crew of ORV Sagar Kanya are thanked for their help. Analytical expenses, including AMS dating, were largely met from CSIR networked project on Ridge studies (COR 006). Ms. Naman helped in shipboard sampling and sample processing in the shore laboratory. NOSAMS facility at WHOI, USA is thanked for AMS dating. Two journal reviews were thorough and extremely helpful and we thank both the anonymous reviewers and editor Gert De Lange for their painstaking and positive comments. Drs. Almogi-Labin and Klöcker have provided the digital data of pteropod counts from their published papers. This is National Institute of Oceanography contribution no. 


\section{References}

Almogi-Labin, A., Reiss, Z., 1977. Quaternary pteropods from Israel. Revista Espańola Micropaleontologia 9, 5-48.

Almogi-Labin, A., 1982. Stratigraphic and Paleoceanographic significance of late Quaternary pteropods from deep-sea cores in the Gulf of Aqaba (Elat) and northern most Red Sea. Marine Micropaleontology 7, 53-72.

Almogi-Labin, A., Luz, B., Duplessy, J.C., 1986. Quaternary paleoceanography, pteropod preservation and stable isotope record of the Red Sea. Palaeogeography, Palaeoclimatology, Palaeoecology $57,195-211$.

Almogi-Labin, A., Hemleben, C., Meischner, D., Erlenkeuser, H., 1991. Paleoenvironmental events during the last 13,000 years in the central Red Sea as recorded by pteropoda. Paleoceanography 6, 83-98.

Almogi-Labin, A., Hemleben, C., Meischner, D., 1998. Carbonate preservation and climate changes in the central Red Sea during the last $380 \mathrm{ka}$ as recorded by pteropods. Marine Micropaleontology $33,87-107$.

Almogi-Labin, A., Schmiedl, G., Hemleben, C., Siman-Tov, R., Segl, M., Meischner, D., 2000. The Influence of the NE winter monsoon on productivity changes in the Gulf of Aden, NW Arabian Sea, during the last $530 \mathrm{Ka}$ as recorded by foraminifera. Marine Micropaleontology 40, 295-319.

Bè, A.W.H., Gilmer, R.W., 1977. A zoogeographic and taxonomic review of euthecosomatous pteropoda. in: Ramsay, A.T.S., Oceanic Micropaleontology 1, Academic, Sanfrancisco, California. pp. 733-808.

Berger, W.H., 1975. Deep-sea carbonates: dissolution profiles from foraminiferal preservation. Cushman Foundation, Journal of Foraminiferal Research, Special Publication 13, 82-86.

Berger, W.H., 1977. Deep-sea carbonate and the deglaciation preservation spike in pteropods and foraminifera. Nature 269, 301-304.

Berger, W.H., 1978. Deep-Sea carbonate: pteropod distribution and the aragonite compensation depth. Deep-Sea Research 25, 447-452.

Berner, R.A., Honjo, S., 1981. Pelagic sedimentation of aragonite: its geochemical significance. Science 211, 940-942.

Bhattacharjee, D., Bandyopadhyay, R.R., 2002. Occurrence of pteropod assemblages in seabed sediments and nature of ACD in the Andaman Sea, in: Four decades of Marine Geosciences in 
India-A retrospect, Proceedings of National Seminar. 150 year celebration of GSI, Kolkata, pp. 89-96.

Böning, P., Bard, E., 2009. Millennial/centennial-scale thermocline ventilation changes in the Indian Ocean as reflected by aragonite preservation and geochemical variations in Arabian Sea sediments. Geochimica et Cosmochimica Acta 73, 6771-6788.

Brown, B.E., 2007. Coral reefs of the Andaman Sea-an integrated perspective, in: Gibson, $\quad$ R.N., Atkinson, R.J.A., Gordon, J.D.M. (Eds.), Oceanography and Marine Biology: An annual Review 45. Taylor and Francis, pp. 173-194

Butzin, M., Prange, M., Lohmann, G., 2005. Radiocarbon simulations for the glacial ocean: the effects of wind stress, Southern Ocean sea ice and Heinrich events. Earth and Planetary Science Letters $235,45-61$.

Colin, C., Kissel, C., Blamart, D., Turpin, L., 1998. Magnetic properties of sediments in the Bay of Bengal and the Andaman Sea: impact of rapid North Atlantic Ocean climatic events on the strength of the Indian monsoon. Earth and Planetary Science Letters 160, 623-635.

Cullen, J., 1981. Microfossil evidence for changing salinity patterns in the Bay of Bengal over the last 20,000 years. Palaeogeography, Palaeoclimatology, Palaeoecology 35, 315-356.

Diester-Haass, L., Schrader, H.J., Thiede, J., 1973. Sedimentological investigations of two pelagic ooze cores off Cape Barbas, North-West Africa. Meteor Forschungs-Ergebnisse C 16, 19-66

Diester-Haass, L., 1977. Radiolarian/planktonic foraminiferal ratios in a coastal upwelling region. Journal of Foraminiferal Research 7, 26-33.

Diester-Hass, L., Van der Spoel, S., 1978. Late Pleistocene pteropods-rich sediment layer in the Northeast Atlantic and protoconch variation of Clio Pyramidata linné 1767. Palaeogeography, Palaeoclimatology, Palaeoecology 24, 85-109.

Duplessy, J.C., 1982. Glacial to interglacial contrasts in the northern Indian Ocean, Nature 295, 494498.

Fabry, V.J., 1990. Shell growth rates of pteropod and heteropod molluscs and aragonite production in the open ocean: implications for the marine carbonate system. Journal of Marine Research 48, 209-222.

Fabry, V.J., Deuser, W.G., 1991. Aragonite and magnesium calcite fluxes to the deep Sargasso Sea. Deep-Sea Research 38, 713-728. 
Fabry, V.J., Deuser, W.G., 1992. Seasonal changes in the isotopic compositions and sinking fluxes of euthecosomatous pteropod shells in the Sargasso Sea. Paleoceanography 7, 195-213.

Feely, R., Sabine, C., Lee, K., 2004. Impact of anthropogenic $\mathrm{CO}_{2}$ on the $\mathrm{CaCO}_{3}$ system in the oceans. Science 305, 362-66

Ganssen, G. and Lutze, G.F., 1982. The aragonite compensation depth at the northeastern Atlantic continental margin. Meteor Forschungs-Ergebnisse 36, 57-59.

Gerhardt, S., Henrich, R., 2001. Shell preservation of Limacina inflata (pteropoda) in surface sediments from the Central and South Atlantic Ocean: a new proxy to determine the aragonite saturation state of water masses. Deep-Sea Research I 48, 2051-2071.

Herman, Y., Rosenberg, P.E., 1969. Pteropods as bathymetric indicators. Marine Geology 7, 169-173.

Ivanova, E.M., 2000. Late Quaternary Monsoon history and paleoproductivity of the western Arabian Sea. Ph.D. Thesis, Free University. Netherlands.

Janekarn, V., Hylleberg, J., 1989. Coastal and offshore primary production along the west coast of Thailand (Andaman Sea) with notes on physical chemical variables. Phuket Marine Biology Centre Research Bulletin 51, 1-19.

Kamesh Raju, K.A., Ramprasad, T., Rao, P.S., Rao, B.R., Varghese, J., 2004. New insights in to the tectonic evolution of the Andaman Basin, northeast Indian Ocean. Earth and Planetary Science Letters 221, 145-162.

Kleypas, J.A., Buddemeier, R.W., Archer, D., Gattuso, J.P., Langdon, C., Opdyke, B.N., 1999. Geochemical consequences of increased atmospheric $\mathrm{CO}_{2}$ on coral reefs. Science 284, 118-120.

Klöcker, R., Ganssen, G., Jung, S.J.A., Kroon, D., Henrich, R., 2006. Late Quaternary millennial-scale variability in pelagic aragonite preservation off Somalia. Marine Micropaleontology 59, 171183.

Klöcker, R., Henrich, R., 2006. Recent and Late Quaternary pteropod preservation on the Pakistan shelf and continental slope. Marine Geology 231, 103-111.

Lalli, C.M., Gilmer, R.W., 1989. Pelagic snails. Stanford University Press, Stanford, California.

Martinson, D.G., Pisias, N.G., Hays, J.D., Imbrie, J., Moore, T.C., Shackleton, N.J., 1987. Age dating and the orbital theory of the ice ages: development of a high-resolution 0 to 300,000 year chronostratigraphy. Quaternary Research 27, 1-29. 
McGowan, J.A., 1989. Pelagic ecology and Pacific climate. Geophysical Monograph 55. Washington, D.C.

Millero, F.J., 1996. Chemical Oceanography. CRC Press, Boca Raton, FL. Millero, F.J., Degler, E.A., O'Sullivan, D.W., Goyet, C., Eischeid, G., 1998. The carbon dioxide system in the Arabian Sea. Deep-Sea Research II 45, 2225-2252.

Milliman, J.D., Troy, P.J., Balch, W.M., Adams, A.K., Li, Y.H., Meckenzie, F.T., 1999. Biologically mediated dissolution of calcium carbonate above the chemical lysocline?. Deep-Sea Research I 46, 1653-1669.

Milliman, J.S., Meade, R.H., 1983. World-wide delivery of river sediment to the oceans. Journal of Geology 91, 1-21.

Morse, J.W., Arvidson, R.S., 2002. The dissolution kinetics of major sedimentary carbonate minerals. Earth Science Review 58, 51-84.

Mucci, A., 1983. The solubility of calcite and aragonite in sea water at various salinities, temperature and one atmosphere total pressure. American Journal of Science 283, 780-799.

Naqvi, W.A., Charles, C.D., Fairbanks, R.G., 1994. Carbon and oxygen isotopic records of benthic foraminifera from the Northeast Indian Ocean: implications on glacial-interglacial atmospheric CO2 changes. Earth and Planetary Science Letters 121, 99-110.

Panchang, R., Nigam, R., Riedel, F., Janssen, A.W., Hla, U.K.Y., 2007. A review of the studies on pteropods from the northern Indian Ocean region with a report on the pteropods of Irrawaddy continental shelf off Myanmar (Burma). Indian Journal of Marine Science 36(4), 384-398.

Peterson, L.C., Prell, W.L., 1985. Carbonate dissolution in recent sediments of the eastern Equatorial Indian Ocean: preservation pattern and carbonate loss above the lysocline. Marine Geology 64, 259-290.

Rai, A.K., Singh, V.B., Maurya, A.S., Shukla, S., 2008. Ventilation of northwestern Arabian Sea Oxygen Minimum Zone during last 175 kyrs: A pteropod record at ODP Site 728A. Current Science 94, 480-485.

Rao, L.V.G., Jayaraman, R., 1968. Hydrographical features of the southern and central Bay of Bengal during the transition period between winter and summer. Bulletin National Science of India 38, 184-205.

Rashid, H., Flower, B.P., Poore, R.Z., Quinn, T.M., 2007. A $~ 25$ ka Indian Ocean monsoon variability record from the Andaman Sea. Quaternary Science Reviews 26, 2586-2597. 
Reichart, G.J., Lourens, L.J., Zachariasse, W.J., 1998. Temporal variability in the northern Arabian Sea Oxygen Minimum Zone (OMZ) during the last 225,000 years. Paleoceanography 13, 607-621.

Reichart, G.J., Nortier, J., Versteegh, G.J.M., Zachariasse, W.J., 2002. Periodical breakdown of the Arabian Sea oxygen minimum zone caused by deep convective mixing, in: Clift, P.D., Kroon, D., Craig, J., Gaedicke, C. (Eds.), Geological Society of London, Special Publication. pp. 407420 .

Reiss, Z., Luz, B., Almogi-Labin, A., Halicz, E., Winter, A., Wolf, M., Ross, D.A., 1980. Late Quaternary Paleoceanography of the Gulf of Aqaba (Elat), Red Sea. Quaternary Research 14, 294-308.

Rodolfo, K., 1969. Sediments of the Andaman Basin, north eastern Indian Ocean. Marine Geology 7, $371-402$.

Rostek, F., Bard, E., Beaufort, L., Sonzogni, C., Ganssen, G., 1997. Sea surface temperature and productivity records for the past 240 ka in the Arabian Sea. Deep-Sea Research II 44, 1461-1480.

Rottman, M.L., 1978. Ecology of Recurrent Groups of Pteropods, Euphausiids and Chaetognaths in the Gulf of Thailand and the South China Sea. Marine Biology 48, 63-78.

Rottman, M.L., 1980. Net tow and surface sediment distributions of pteropods in the South China Sea region: comparison and oceanographic implications. Marine Micropaleontology 5, 71-110.

Ruddiman, W.F., Heezen, B.C., 1967. Differential solution of planktonic foraminifera. Deep-Sea Research 14, 801-808.

Sakthivel, M., 1968. A preliminary report on the distribution and relative abundance of Euthecosomata with a note on the seasonal variation of Limacina species in the Indian Ocean. Bulletin of National Institute of Science of India 38, 700-717.

Sarkar, A., Ramesh, R., Bhattacharya, S.K., Rajagopalan, G., 1990. Oxygen isotope evidence for a stronger winter monsoon current during the last glaciation. Nature 343, 549-551.

Sarma, V.V.S.S., Narvekar, P.V., 2001. A study on inorganic carbon components in the Andaman Sea during the post monsoon season. Oceanologica Acta 24, 125-134.

Schulte, S., Müller, P.J., 2001. Variations of sea surface temperature and primary productivity during Heinrich and Dansgaard-Oeschger events in the north eastern Arabian Sea. Geo-Marine Letters $21,168-175$.

Schulz, H., von Rad, U., Erlenkeuser, H., 1998. Correlation between Arabian Sea and Greenland climate oscillations of the past 110,000 years. Nature 393, 54-57. 
Sengupta, R., Moraes, C., George, M.D., Kureishy, T.W., Noronha, R.J., Fondekar, S.P., 1981. Chemistry and hydrography of Andaman Sea. Indian Journal Marine Science 10, 228-233.

Shackleton, N.J., 1977. Carbon-13 in Uvigerina: Tropical rain forest history and the equatorial Pacific carbonate dissolution cycles, in: Anderson, N.R., Malahoff, A. (Eds.), The Fate of Fossil Fuel $\mathrm{CO}_{2}$ in the Oceans. Plenum, New York, pp. 401-427.

Singh, A.D., 1998. Late Quaternary oceanographic changes in the eastern Arabian Sea: Evidence from planktic foraminifera and Pteropods. Journal of Geological Society of India 52, 203-212.

Singh, A.D., Kroon, D., Ganeshram, R.S., 2006. Millenial Scale Variations in productivity and OMZ intensity in the eastern Arabian Sea. Journal of Geological Society of India 68, 369-377.

Sirocko, F., Sarnthein, M., Erlenkeuser, H., Lange, H., Arnold, M., Duplessy, J.C., 1993. Century-scale events in monsoonal climate over the past 24,000 years. Nature 364, 322-324.

Van der Spoel, S., 1967. Euthecosomata, a group with remarkable developmental stages (Gastropoda, Pteropoda). J. Noorduijn en Zoon N.V, Gorinchem, Netherlands. pp375.

Varkey, M.J., Murthy, V.S.N., Suryanarayana, A., 1996. Physical oceanography of the Bay of Bengal and Andaman Sea. Oceanography Marine Biology Annual Review 34, 1-70.

Volbers, A.N.A., Henrich, R., 2002. Late Quaternary variations in carbonate preservation of deep-sea sediments in the Northern Cape Basin: results from a multi proxy approach. Marine Geology $180,203-220$.

von Rad, U., Schulz, H., Riech, V., den Dulk, M., Berner, U., Sirocko, F., 1999. Multiple monsooncontrolled breakdown of oxygen-minimum conditions during the past 30,000 years documented in laminated sediments off Pakistan. Palaeogeography, Palaeoclimatology, Palaeoecology 152, 129-161.

Wang, L., Jian, Z., Chen, J., 1997. Late Quaternary pteropods in the South China Sea: carbonate preservation and paleoenvironmental variation. Marine Micropaleontology 32, 115-126.

Weninger, B., Jöris, O., Danzeglocke, U., 2007. CalPal-2007 Cologne Radiocarbon Calibration \& Palaeoclimate Research Package, http://www.calpal.de 


\section{Figure captions}

Fig. 1. Location of core SK 168/GC 1, Andaman Sea, with an additional site under discussion (AAS 11/GC 1) in the Eastern Indian Ocean (modified from Kamesh Raju et al., 2004): a) bathymetry of Andaman Sea along with core locations; b) salinity (annual salinity at the surface, World ocean atlas, 2009, www.nodc.noaa.gov) and monsoon currents in Andaman Sea black arrow-summer monsoon, yellow arrow-winter monsoon, (modified from Brown, 2007 reference therein)

Fig. 2. a) $\delta^{18} \mathrm{O}$ record of planktic foraminifera (G. ruber) of core SK 168/GC 1; arrow marks represent AMS ${ }^{14} \mathrm{C}$ dating horizons; b) Plot of $\mathrm{AMS}{ }^{14} \mathrm{C}$ dates calibrated to calendar age (black circles) and isotope stage boundary of 2 and 3 (grey circle) as a function of depth along with sedimentation rates.

Fig. 3. Absolute abundance of total pteropods and major species in Core SK 168/GC 1 with respect to climatic events Younger Dryas (YD), Bølling/Allerød (B/A), Last Glacial Maxima (LGM) and Heinrich Events (HE): a) Total pteropods; b) L. inflata; c) L. trochiformis d) Diacria quadridentata e) Clio convexa f) Styliola subula g) Creseis acicula.

Fig. 4. Proxies for aragonite / carbonate dissolution and productivity of core SK 168/GC 1 with respect to climatic events Younger Dryas (YD), Bølling/Allerød (B/A), Last Glacial Maxima (LGM) and Heinrich Events (HE): a) Absolute abundance of pteropods; b) Pteropod fragmentation ratio: fragments/(fragments+total pteropods); c) Carbonate dissolution proxy: Planktic foraminifera resistant species (\%) (Total percentage of P. obliquiloculata, G. menardii, N. dutertrei and S. dehiscence); Productivity proxies d) $\mathrm{C}_{\mathrm{org}}(\%)$; e) G. bulloides\% (Vertical solid line indicates average value).

Fig.5. Comparison of available deglacial pteropod preservation events in the Northern Indian Ocean region with respect to climatic events Younger Dryas (YD), Bølling/Allerød (B/A), Last Glacial Maxima (LGM) and Heinrich Events (HE): Andaman Sea: a) Total pteropods in SK 168/GC-1; b) Total pteropods AAS 11/GC 1; Eastern Arabian Sea c) Total pteropods in SK 17 off Goa (Singh et.al., 2006); d) Pteropods\% in SO 90/137 KA, off Pakistan (Klöcker and Heinrich, 2006); Western Arabian Sea e) Total pteropods in KL 15, Gulf of Aden (Almogi-Labin et al., 2000); f) Pteropods\% NIOP 905, off Somalia (Klöcker et al., 2006); Northern Arabian Sea g) Aragonite\% (Aragonite contents determined using X-ray diffractometry) MD 042876 (Böning and Bard, 2009). As seen in the figure, the best preservation period is synchronous in all the records and begins at early deglaciation suggesting a regional scale phenomenon. 
Table: 1 AMS ${ }^{14} \mathrm{C}$ dates and calibrated ages of sediment samples for SK 168/GC 1

\begin{tabular}{|l|l|l|l|l|}
\hline $\begin{array}{l}\text { Depth in core } \\
(\mathrm{cm})\end{array}$ & Material & $\begin{array}{l}\text { Accession } \\
\text { No. }\end{array}$ & $\begin{array}{l}\text { Radiocarbon } \\
\text { age } \\
\left({ }^{14} \text { C age in }\right. \\
\text { years })\end{array}$ & $\begin{array}{l}\text { Calendar age } \\
\text { (Cal year BP) }\end{array}$ \\
\hline SK168/0-2 & $\begin{array}{l}\text { mixed G. ruber and } \\
\text { G. sacculifer }\end{array}$ & OS-64674 & $1440 \pm 30$ & $883 \pm 47$ \\
\hline SK168/75-77 & $\begin{array}{l}\text { mixed G. ruber and } \\
\text { G. sacculifer }\end{array}$ & OS-64675 & $9650 \pm 30$ & $10361 \pm 76$ \\
\hline SK168/95-97 & $\begin{array}{l}\text { mixed G. ruber and } \\
\text { G. sacculifer }\end{array}$ & OS-64676 & $10850 \pm 50$ & $12321 \pm 178$ \\
\hline SK168/215-220 & $\begin{array}{l}\text { mixed G. ruber and } \\
\text { G. sacculifer }\end{array}$ & OS-64677 & $27900 \pm 220$ & $32055 \pm 215$ \\
\hline SK168/330-335 & $\begin{array}{l}\text { mixed G. ruber and } \\
\text { G. sacculifer }\end{array}$ & OS-64678 & $41300 \pm 530$ & $44363 \pm 820$ \\
\hline
\end{tabular}


Table. 2 List of pteropod species encountered in this study.

\begin{tabular}{|l|l|l|}
\hline Sl.No & Species & Remarks \\
\hline 1 & Limacina inflata (d' Orbigny) & $\begin{array}{l}\text { Most abundant mesopelagic species throughout } \\
\text { the core, Mono-specific at certain depths, It a a } \\
\text { warm belt species and does not live in high } \\
\text { latitudes. Most common pteropod in gyre centers } \\
\text { in all major oceans and areas known to be } \\
\text { oligotrophic (Bè and Gilmer, 1977; McGowan, } \\
\text { 1989). Transparent species were encountered at } \\
\text { glacial sections. }\end{array}$ \\
\hline 2 & L. trochiformis (d' Orbigny) & $\begin{array}{l}\text { Second most abundant species, tropical warm } \\
\text { water epipelagic taxon and known to be a typical } \\
\text { upwelling species (Bè and Gilmer 1977). }\end{array}$ \\
\hline 3 & L. bulimoides (d' Orbigny) & $\begin{array}{l}\text { Cool water mesopelagic species, more abundant } \\
\text { in glacial sections }\end{array}$ \\
\hline 4 & Creseis chierchiae (Boas) & $\begin{array}{l}\text { Epipelagic species, More abundant in LGM } \\
\text { sections }\end{array}$ \\
\hline 5 & C. acicula (Rang) & $\begin{array}{l}\text { Epipelagic species, present only in sediment } \\
\text { representing YD, H1 and LGM }\end{array}$ \\
\hline 6 & C. virgula (Rang) & $\begin{array}{l}\text { Epipelagic species, a very rare member of the } \\
\text { pteropod assemblage }\end{array}$ \\
\hline 7 & C. conica (Rang) & $\begin{array}{l}\text { Epipelagic species, were found only in glacial } \\
\text { sections }\end{array}$ \\
\hline 8 & $\begin{array}{l}\text { Diacria quadridentata } \\
\text { (de Blainville) }\end{array}$ & $\begin{array}{l}\text { Epipelagic species, more abundant in YD, H1 and } \\
\text { LGM sections }\end{array}$ \\
\hline 9 & D. trispinosa (de Blainville) & Mesopelagic species, very rare \\
\hline 10 & Clio cuspidata (Bosc) & Mesopelagic species, very rare \\
\hline 11 & C. pyramidata (Linnaeus) & Mesopelagic species, very rare \\
\hline 12 & C. convexa (Boas) & $\begin{array}{l}\text { Mesopelagic species, More abundant in YD, H1 } \\
\text { and LGM sections }\end{array}$ \\
\hline Gaimard) & $\begin{array}{l}\text { Mesopelagic species, very rare and partly } \\
\text { fragmented forms were also noticed }\end{array}$ \\
\hline
\end{tabular}


Table. 3 Comparison of available pteropod preservation records during Holocene.

\begin{tabular}{|c|c|c|c|}
\hline Core location & $\begin{array}{l}\text { Water } \\
\text { Depth (m) }\end{array}$ & $\begin{array}{l}\text { Pteropods during } \\
\text { Holocene }\end{array}$ & Reference \\
\hline $\begin{array}{l}\text { Andaman Sea } \\
\text { SK 168/GC1 } \\
\text { AAS } 11 / G C 1 \\
\text { RVS2/GC3 }\end{array}$ & $\begin{array}{l}2064 \\
2900 \\
2301\end{array}$ & $\begin{array}{l}\text { Absent } \\
\text { Absent } \\
\text { Absent }\end{array}$ & $\begin{array}{l}\text { This study } \\
\text { Unpublished } \\
\text { Unpublished }\end{array}$ \\
\hline $\begin{array}{l}\text { off Myanmar } \\
\text { GC-5 }\end{array}$ & 37 & Absent in the top $80 \mathrm{~cm}$ & Panchang et al. (2007) \\
\hline $\begin{array}{l}\text { Gulf of Aden } \\
\text { KL } 15\end{array}$ & 1631 & $\begin{array}{l}\text { Absent during the last } \\
8.2 \mathrm{ka}\end{array}$ & Almogi-Labin et al. (2000) \\
\hline $\begin{array}{l}\text { Red Sea } \\
\text { KL } 11\end{array}$ & 825 & Good preservation & Almogi-Labin et al. (1998) \\
\hline $\begin{array}{l}\text { Eastern Arabian Sea } \\
\text { SK } 17\end{array}$ & 840 & Absent during last $7 \mathrm{ka}$ & Singh et al. (2006) \\
\hline $\begin{array}{l}\text { Northern Arabian Sea } \\
\text { SO } 90137 \text { KA }\end{array}$ & 573 & Absent during last $8 \mathrm{ka}$ & $\begin{array}{l}\text { Klocker and Heinrich, } \\
(2006)\end{array}$ \\
\hline $\begin{array}{l}\text { Western Arabian Sea } \\
\text { off Somalia } 905\end{array}$ & 1586 & Absent during last $8 \mathrm{ka}$ & Klocker et al. (2006) \\
\hline $\begin{array}{l}\text { South China Sea } \\
\text { (Western Pacific } \\
\text { region) } \\
\text { SO } 50-37 \mathrm{KL} \\
\text { SO } 498 \mathrm{KL} \\
\text { SCS } 12 \\
\text { RC } 14-79\end{array}$ & $\begin{array}{l}2695 \\
1040 \\
543 \\
706\end{array}$ & $\begin{array}{l}\text { Absent during last } 7 \mathrm{ka} \\
\text { Absent during last } 8 \mathrm{ka} \\
\text { Traces } \\
\text { Traces }\end{array}$ & Wang et al. (1997) \\
\hline
\end{tabular}




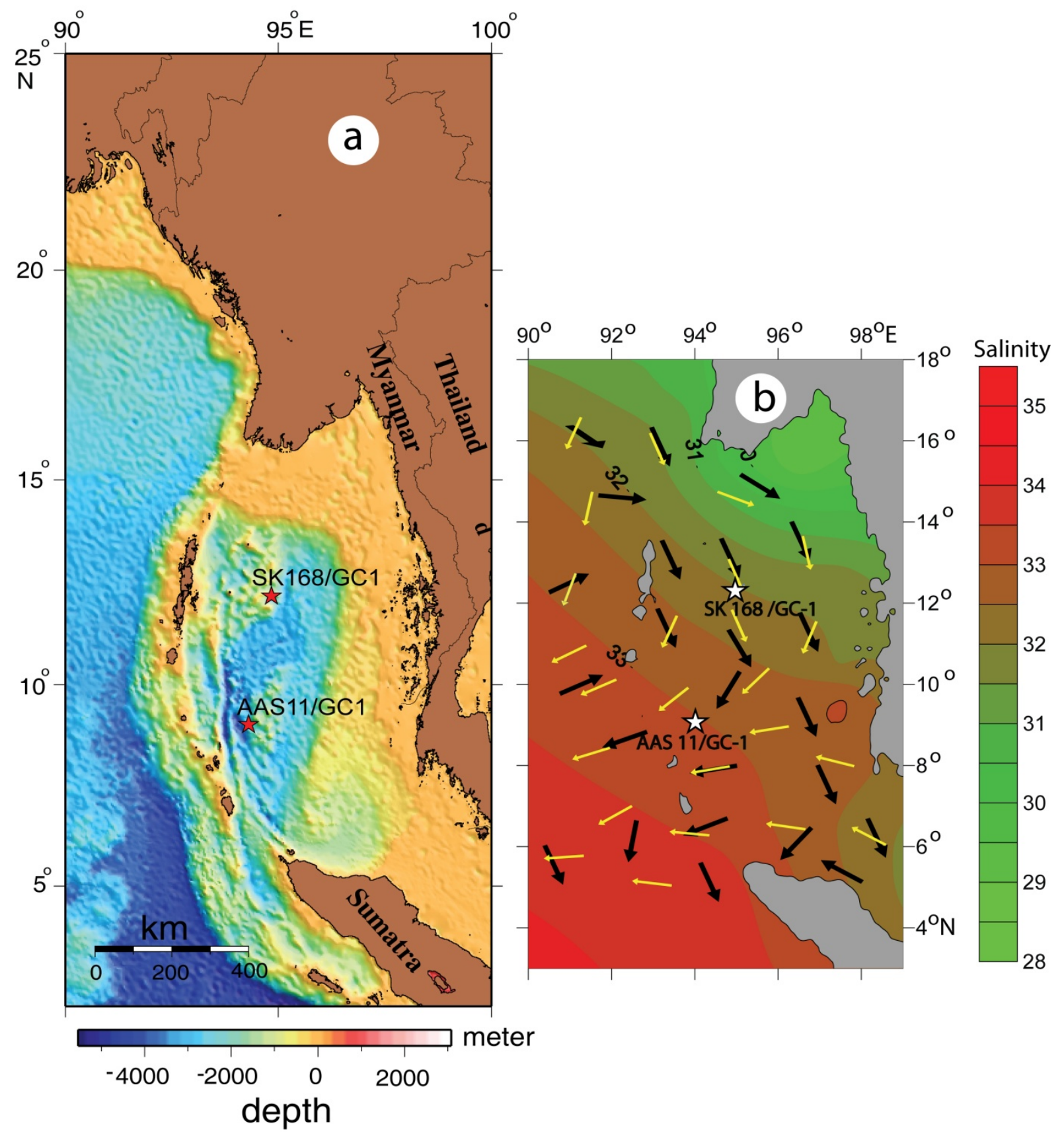

Fig. 1.

(Sijinkumar et al., 2010) 


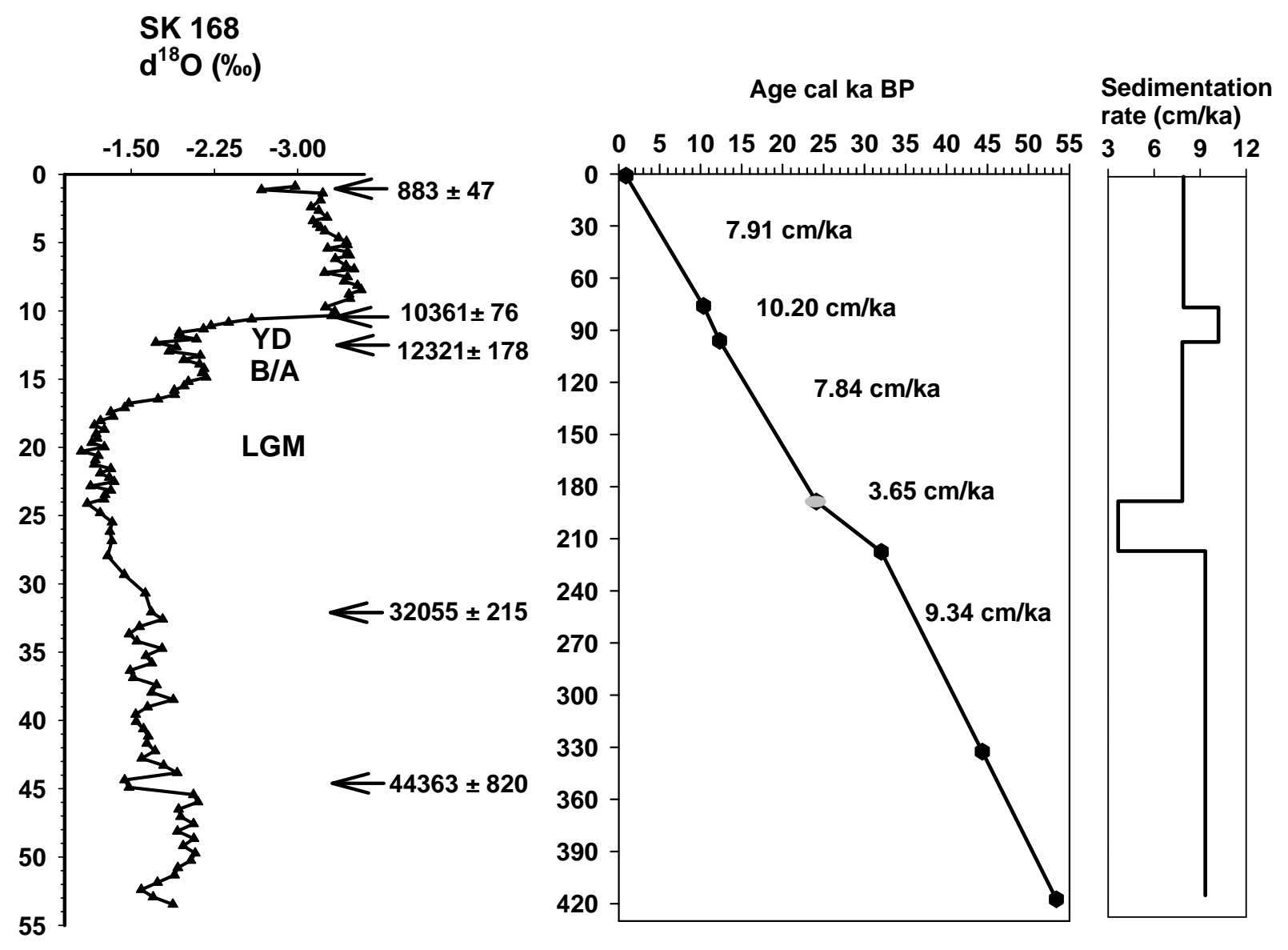

Fig. 2.

(Sijinkumar et al., 2010) 


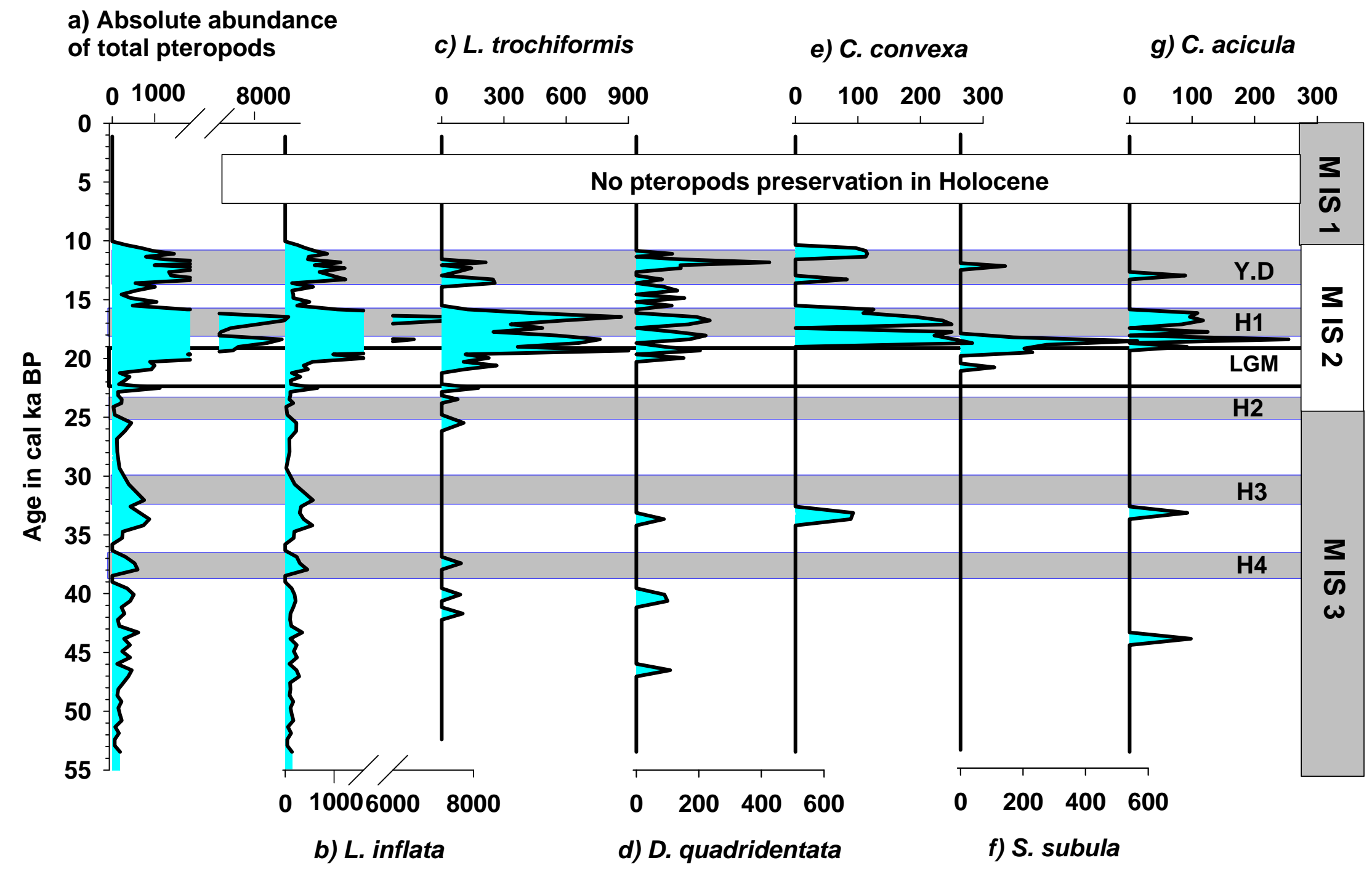

Fig. 3.

(Sijinkumar et al., 2010) 


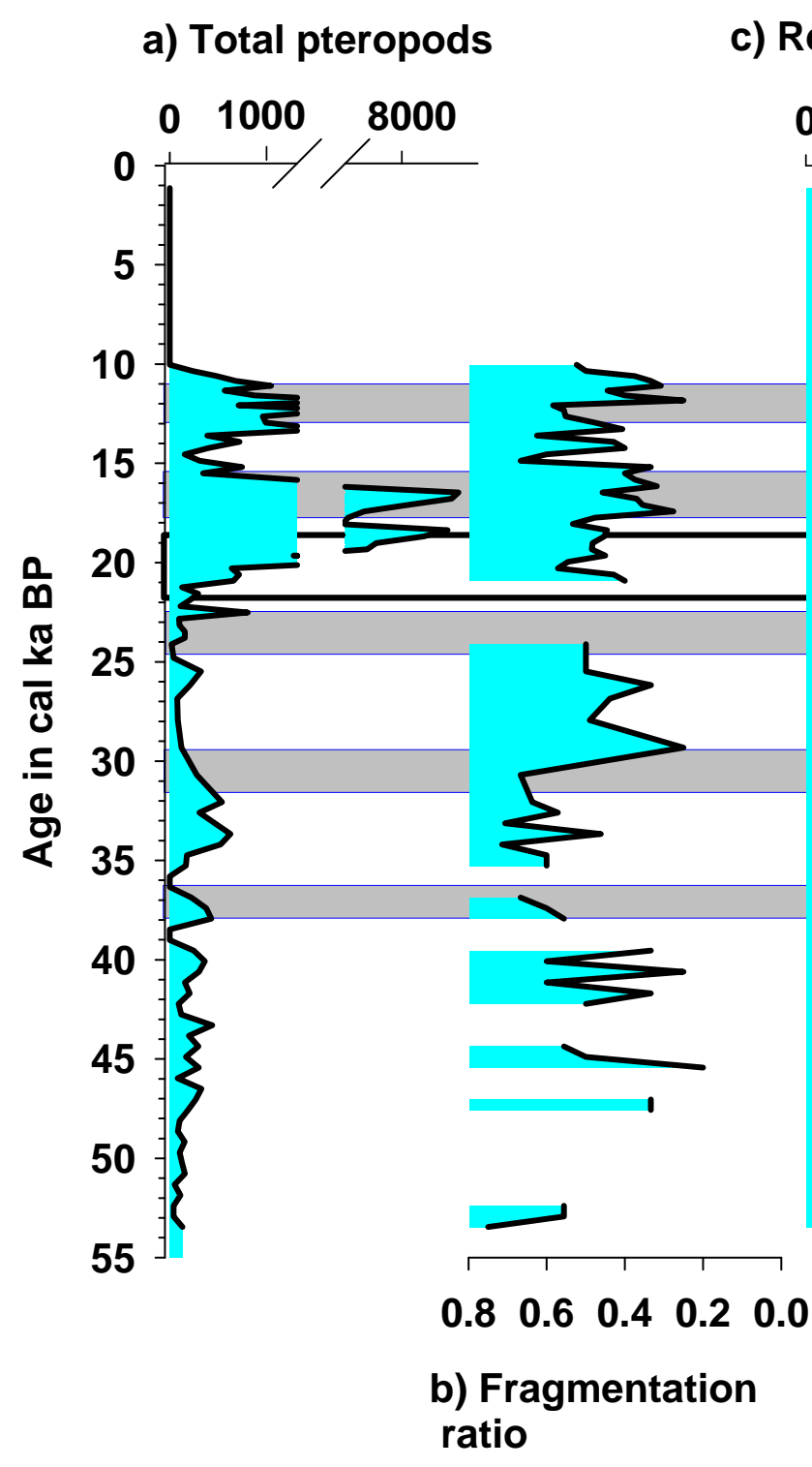

c) Resistant Species (\%)

e) G. bulloides \%
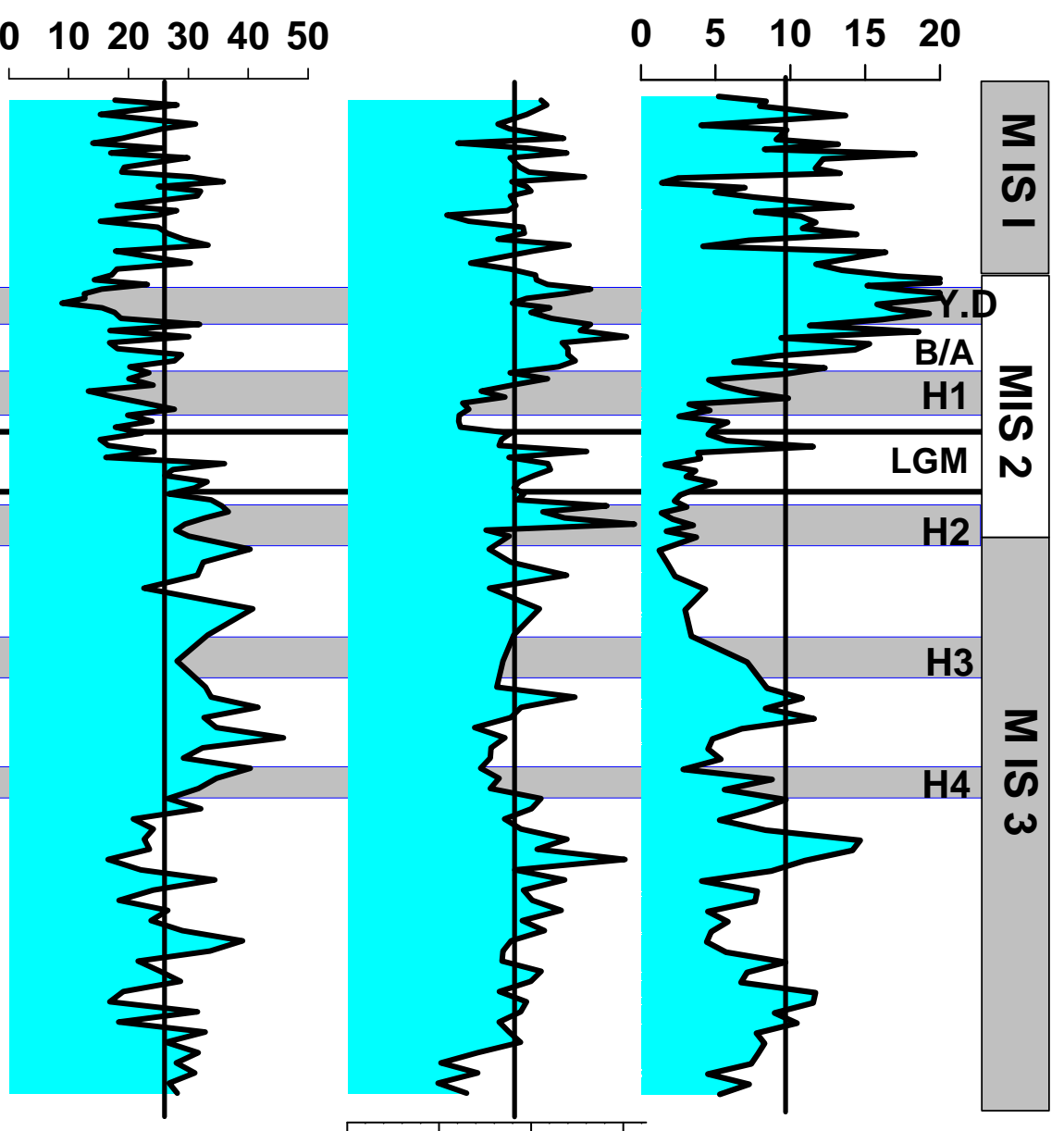

$\begin{array}{llll}0.4 & 0.8 & 1.2 & 1.6\end{array}$

d) TOC $\%$

Fig. 4.

(Sijinkumar et al., 2010) 


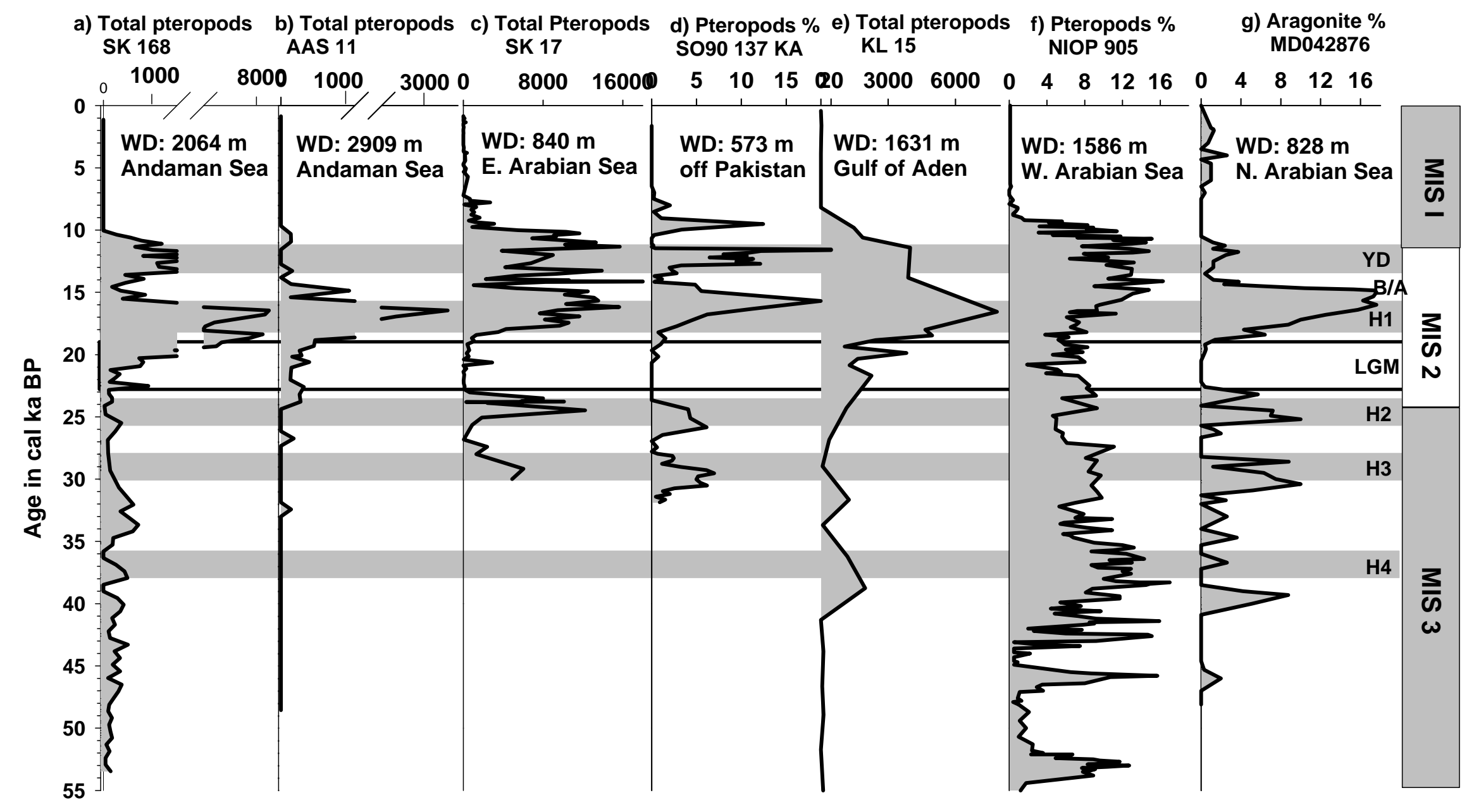

Fig. 5.

(Sijinkumar et al., 2010) 